\title{
Preparation and Characterization of Alkaline Anion Exchange Membrane for Fuel Cells Application
}

\author{
Ganmin Zeng, Jing Han, Beibei Dai, Xiaohui Liu, Jinkun Li, Chuntao Chen, \\ Jiazhi Yang, and Dongping Sun
}

Chemicobiology and Functional Materials Institute, Nanjing University of Science and Technology, Nanjing,

Jiangsu 210094, China

Correspondence should be addressed to Jiazhi Yang; jzhyangb504@163.com

Received 18 January 2017; Revised 6 April 2017; Accepted 15 May 2017; Published 19 June 2017

Academic Editor: Marco Rossi

Copyright ( 2017 Ganmin Zeng et al. This is an open access article distributed under the Creative Commons Attribution License, which permits unrestricted use, distribution, and reproduction in any medium, provided the original work is properly cited.

\begin{abstract}
Alkaline anion exchange membrane (AAEM) plays an important role in the development of fuel cell. In this research, the electrostatic spinning technology was used to prepare AAEM. We use $\mathrm{BC} / \mathrm{TiO}_{2}$ membrane as substrate by introduced quaternary ammonium groups to prepare $\mathrm{BC} / \mathrm{TiO}_{2} / \mathrm{CHPTAC}$ (3-chloro-2-hydroxypropyl trimethyl ammonium chloride) composite membranes. The as-prepared composite membrane was characterized by XRD, SEM, XPS, and TG methods. It was found that $\mathrm{BC} / \mathrm{TiO}_{2} / \mathrm{CHPTAC}(0.05 \mathrm{~g})$ membrane exhibited high thermal stability and better comprehensive performance. The degree of substitution (DS), water uptake, and ion-exchange capacity (IEC) of $\mathrm{BC} / \mathrm{TiO}_{2} / \mathrm{CHPTAC}$ membranes were investigated. The results showed that the DS, water uptake, and IEC of $\mathrm{BC} / \mathrm{TiO}_{2} / \mathrm{CHPTAC}$ membrane were $1.16,140 \%$, and $1 \mathrm{mmol} \cdot \mathrm{g}^{-1}$, respectively. We believe this composite membrane with excellent performances can promise many applications in fuel cells.
\end{abstract}

\section{Introduction}

Recently, with the escalation of the energy crisis, increasing attention has been paid to the research on fuel cell. Fuel cells for residential applications have proven their ability to produce electricity with lower heating value efficiencies up to $60 \%$ using nature gas [1]. Efficiencies over $70 \%$ are projected when they are combined with gas turbines or reciprocating internal combustion engines $[2,3]$. Among them, the proton exchange membrane fuel cell (PEMFC) is the most promising application, because it is typical device that can continuously convert chemical energy into electric energy and a limited amount of thermal energy [4]. Membrane is one of the core components of PEMFC, including proton exchange membrane fuel cell membrane (PEMFCM) and anion exchange membrane fuel cell membrane (AEMFCM). AEMFCM is designed to provide sufficient hydroxyl ions for ionic exchanges and isolate anode to cathode during electrochemical reactions. In the anion exchange membrane fuel cell (AEMFC), the AEMFCM should have excellent chemical, thermal, and mechanical stability as well as high conductivity and low cost. Therefore, the preparation of high performance of AEMFCM becomes one of the key researches [5-7].

At present, polyvinyl alcohol (PVA) [8] and chitosan (CS) are two kinds of commonly used matrices. Kim et al. [9] prepared quaternized $\mathrm{PVA} / \mathrm{SiO}_{2}$ hybrid membrane and used it for direct methanol fuel cell. As it is indicated that methanol permeability $\left(10^{-7}-10^{-8}\right)$ of the hybrid membrane is low, it meets the requirement of fuel cell. However, the ion conduction of $\mathrm{PVA} / \mathrm{SiO}_{2}$ hybrid membrane is poor. Xiong et al. [10] synthesized quaternized chitosan through chitosan and glycidyl trimethyl ammonium chloride. And the composite membrane is prepared by mixing the quaternized chitosan with quaternary ammonium polyvinyl alcohol (QAPVA). The maximum conductivity of this composite membrane can reach $8.37 \times 10^{-3} \mathrm{~S} / \mathrm{cm}$. But the stability of the membrane is bad and it can be completely dissolved in water for short time. Therefore, the research and development of new materials preparation AEMFCM are crucial.

According to some researches, bacterial cellulose (BC) membranes have many excellent properties, such as high purity (99\%-100\%), superfine (nanoscale), high moisture 
retention and thermal stability, low permeability of gas, and high Young's modulus in wet condition [11, 12]. The AEMFCM was prepared on the basis of BC by electrospinning, not only keeping the above advantages, but also introducing many additional superiorities, for example, high specific surface area, large length-diameter ratio, high quality, large porosity, and controllable membrane thickness [1316]. Otherwise, it is easy to prepare a multifunctional fiber in combination with many technologies by electrospinning. Meanwhile, inducing inorganic particles through physical and chemical methods can enhance chemical and thermal stability of membranes. The organic-inorganic nanocomposite membranes are generally organic polymer composites with inorganic nanoscale building blocks $[17,18]$. The commonly used inorganic materials are $\mathrm{SiO}_{2}$ [19], $(\mathrm{Al}, \mathrm{Mg})_{2}\left(\mathrm{SiO}_{4} \mathrm{O}_{10}\right)(\mathrm{OH})_{2} \cdot n \mathrm{H}_{2} \mathrm{O}[20], \mathrm{Na}_{2}\left[\mathrm{Al}_{2} \mathrm{Si}_{3} \mathrm{O}_{10}\right] \cdot 2 \mathrm{H}_{2} \mathrm{O}$ [21], and $\mathrm{H}_{2} \mathrm{O}_{8} \mathrm{P}_{2} \mathrm{Zr}$ [22]. Among them, $\mathrm{TiO}_{2}$ nanoparticles reveal the function of solid plasticization, high chemical stability, and being nontoxic and odorless, and it was applied in different fields, including environmental protection, energy, and composite material [23]. Yang [24] prepared a $\mathrm{PVA} / \mathrm{TiO}_{2}$ composite membrane through solution casting method and used it in methanol fuel cells with a maximum current density of $7.54 \mathrm{~W} / \mathrm{cm}^{-2}$. These composite membranes may be more suitable for matrix materials of AAEMs.

In this paper, we have adopted the electrostatic spinning technology to prepare the $\mathrm{BC} / \mathrm{TiO}_{2} / \mathrm{CHPTAC}$ nanofibers membrane. This composite membrane keeps high intensity, large ion-exchange capacity, and low cost. Compared with other membranes, the $\mathrm{BC} / \mathrm{TiO}_{2} / \mathrm{CHPTAC}$ composite membrane exhibited comparable performance, thus becoming promising for application in fuel cells.

\section{Experimental Section}

2.1. Materials. BC samples were cultivated using Acetobacter xylinum NUST4.2 through a static fermentation process [25] at $30^{\circ} \mathrm{C}$. They were treated with $0.1 \mathrm{M}$ sodium hydroxide solution at $80^{\circ} \mathrm{C}$ for $2 \mathrm{~h}$ in order to rinse off the bacteria and brought to a neutral $\mathrm{pH}$ value by washing with distilled water several times. LiCl, dimethylacetamide (DMAC), CHPTAC, $\mathrm{NaOH}, \mathrm{TiO}_{2}$, and PVA were purchased from Sinopharm Chemical Reagent Co., Ltd. (analytic grade). All chemicals were used as received without further purification.

2.2. Preparation of $\mathrm{TiO}_{2} / \mathrm{BC}$ Membrane. Certain amount of $\mathrm{BC}$ powder was added to $8 \% \mathrm{LiCl} / \mathrm{DMAC}(\mathrm{w} / \mathrm{w})$ solution. The mixture was stirred at $100^{\circ} \mathrm{C}$ for $1 \mathrm{~h}$ to form a homogeneous $\mathrm{BC} / \mathrm{LiCl} / \mathrm{DMAC}$ solution. Air bubbles were wiped out from the solution by fast centrifugation. Certain amount of $\mathrm{TiO}_{2}$ powder was added to the $\mathrm{BC} / \mathrm{LiCl} / \mathrm{DMAC}$ solution, followed by ultrasonic dispersion. Adjusting to the spinning temperature, humidity, voltage, extrusion rate, and receiving distance, the ultrafine nanofibers were collected by an aluminum foil roller. After being solidified in ethanol and washed by distilled water, $\mathrm{TiO}_{2} / \mathrm{BC}$ regenerated membrane was obtained.
2.3. Preparation of $\mathrm{TiO}_{2} / \mathrm{BC} / \mathrm{CHPTAC-OH}$ Membrane. The above $\mathrm{TiO}_{2} / \mathrm{BC}$ membrane was added to a $250 \mathrm{~mL}$ threenecked bottle and heated in a water bath at $60^{\circ} \mathrm{C}$ for $1 \mathrm{~h}$ with isopropyl alcohol as solvent. Then we added CHPTAC to the above solution according to a certain molar ratio $(10: 1)$ of CHPTAC to anhydroglucose unit in BC. $\mathrm{NaOH}$ ( $2 \mathrm{~mol} / \mathrm{L}$ ) solution was used to adjust the $\mathrm{pH}$ of system. After that, magnetic stirring was continuous for $4-16 \mathrm{~h}$ at certain temperature $\left(25-60^{\circ} \mathrm{C}\right)$. The washed product was finally freeze-dried with lyophilizer to obtain the alkaline anion exchange membranes.

2.4. Preparation of $\mathrm{TiO}_{2} / B C / C H P T A C-O H / P V A$ Membrane. The PVA powder was added to distilled water and stirred at $90^{\circ} \mathrm{C}$ for $2 \mathrm{~h}$ to form a homogeneous and transparent solution (the mass fraction of PVA is $8 \%$ ). $\mathrm{TiO}_{2} / \mathrm{BC} / \mathrm{CHPTAC}$ OH/PVA membranes were soaked into PVA solution. The membranes were transferred onto two glass plates and then dried at $60^{\circ} \mathrm{C}$ to form a sandwich structure. Then the $\mathrm{TiO}_{2} /$ $\mathrm{BC} / \mathrm{CHPTAC}-\mathrm{OH} / \mathrm{PVA}$ alkaline anion exchanged casting membrane was obtained.

2.5. Structure Characterization and Morphology Test. The rheological properties of solution were examined using a rotary viscometer, at a shearing rate from $0.001 \mathrm{~s}^{-1}$ to $0.1 \mathrm{~s}^{-1}$. $\mathrm{X}$-ray diffractometer (XRD) was used to observe the membrane crystalline structure (Bruker D8 ADVANCE, Germany). The samples were scanned over the $2 \theta$ range of $10^{\circ}$ to $80^{\circ}$. The operating voltage and current were $40 \mathrm{kV}(1 \mathrm{kV} / 1$ step) and $30 \mathrm{~mA}$. The radiation was $\mathrm{Cu} \mathrm{K} \alpha$ radiation of wavelength $1.54056 \AA$. Scanning electron microscopy (SEM) was used to observe sample morphology and microstructure. Samples were sputtering coated with gold and examined using a JEOL JSM-6300LV microscope (Japan). Fourier transform infrared spectroscopy (FT-IR) was used to test the structural properties of the samples. Samples were tested with a Fourier transform infrared spectrometer (Bruker EQUINOX55, Germany). The FT-IR spectra were recorded in a spectral range of $500-4000 \mathrm{~cm}^{-1}$ by accumulating 32 scans at a resolution of $4 \mathrm{~cm}^{-1}$. Thermogravimetric analysis (TGA) measurements on samples were performed with a TGA instrument (TGA-50, Shimadzu), from $50^{\circ} \mathrm{C}$ to $800^{\circ} \mathrm{C}$, at a heating rate of $10^{\circ} \mathrm{C} \cdot \mathrm{min}^{-1}$. The samples were swept with $\mathrm{N}_{2}$ during the whole analysis. X-ray photoelectron spectroscopy (XPS) analysis was used to identify the element composition and element valence state. Samples were tested by for a X-ray photoelectron spectrometer (using JEOL PHI Quanta, Japan) using $\mathrm{Al} \mathrm{K} \alpha$ radiation.

\subsection{Membrane Performance Testing}

2.6.1. Degree of Substitution. The degree of substitution (Ds) of the membrane was calculated by the following equation:

$$
\text { Ds }=\frac{162 w \%}{14-151.5 w \%},
$$

where $w$ is the mass fraction of nitrogen. 
2.6.2. Water Uptake. The membranes were freeze-dried at $-55^{\circ} \mathrm{C}$ for $24 \mathrm{~h}$ until constant weight to obtain the dry membranes. Then, they were immersed into deionized water at room temperature for $48 \mathrm{~h}$. After this time, the membranes were taken out, wiped with tissue paper, and quickly weighed on a microbalance. The water uptake (WU) of membrane was calculated from

$$
\mathrm{WU}=\frac{M s-M e}{M e} \times 100 \%,
$$

where $\mathrm{Me}$ and $\mathrm{Ms}$ are the weight of the dry and the corresponding water-swollen membranes, respectively.

2.6.3. Ion-Exchange Capacity. The ion-exchange capacity (IEC, $\mathrm{mmol} / \mathrm{g}$ ) was examined using traditional acid-base titration and calculated by the following equation:

$$
\mathrm{IEC}=\frac{V_{\mathrm{HCl}} \times C_{\mathrm{HCl}}-V_{\mathrm{NaOH}} \times C_{\mathrm{NaOH}}}{M},
$$

where $V_{\mathrm{HCl}}$ is the volume of $\mathrm{HCl}$ immersion membrane, $\mathrm{L}$; $V_{\mathrm{NaOH}}$ is the volume of $\mathrm{NaOH}, \mathrm{L} ; C_{\mathrm{HCl}}$ is the concentration of $\mathrm{HCl}, \mathrm{mol} / \mathrm{L} ; C_{\mathrm{NaOH}}$ is the concentration of $\mathrm{NaOH}, \mathrm{mol} / \mathrm{L} ; M$ is the quality of the dry film, $g$.

2.6.4. Swelling Ratio. The water swelling ratio (SR) of the membranes was investigated by immersing the samples into water at room temperature for $48 \mathrm{~h}$, and the SR was calculated by the following equation:

$$
\mathrm{SR}=\frac{X_{w}-X_{0}}{X_{0}} \times 100 \%,
$$

where $X_{0}$ and $X_{w}$ are the size of dry and wet membranes, respectively.

2.6.5. Mechanical Properties. Mechanical properties of single fibers were measured using SHIMAZUAGS-100NX universal material testing machine (Japan), with a $20 \mathrm{~mm}$ gauge length at a crossbar rate of $50 \mathrm{~mm} \cdot \mathrm{min}^{-1}$. The tensile strength $(P$, $\mathrm{MPa})$ and breaking elongation ratio $\left(\varepsilon_{t}\right)$ of the membranes were calculated by the following equation:

$$
\begin{aligned}
P & =\frac{F}{a \times b}, \\
\varepsilon_{t} & =\frac{G-G_{0}}{G_{0}} \times 100 \%,
\end{aligned}
$$

where $F$ is the breakage load of membranes, $N$; $a$ is the width of samples, $\mathrm{mm}$; $b$ is the thickness of samples, $\mathrm{mm} ; \mathrm{G}_{0}$ is the original distance, $\mathrm{cm} ; \mathrm{G}$ is the breakage distance, $\mathrm{cm}$.

2.6.6. Ionic Conductivity. The ionic conductivity $(\sigma, \mathrm{s} / \mathrm{cm})$ of the membranes was measured with Hioki 3532-50 conductivity meter and calculated by the following equation:

$$
\sigma=\frac{L}{W D R},
$$

where $L$ is the distance of two electrodes, $\mathrm{cm} ; W$ is the width of samples, $\mathrm{cm} ; D$ is the thickness of samples, $\mathrm{cm} ; R$ is the impedance value of the samples, $\Omega$.

\section{Results and Discussions}

\subsection{Characterization of $\mathrm{TiO}_{2} / \mathrm{BC}$ Composite Membrane}

3.1.1. Optimization of BC Electrostatic Spinning. The BC concentration has an important influence on the morphology of electrospun fibers. Figure 1(a) shows the relationship between the viscosity and concentration of $\mathrm{BC}$ solution at $25^{\circ} \mathrm{C}$. We can see that its viscosity keeps pace with concentration of $\mathrm{BC}$ solution, because, with the increasing of concentration, the high molecular weight of solution in unit volume increases; as a result, the degree of molecular chains entanglement is enhanced. Figure 1(b) shows the relationship between viscosity properties of $\mathrm{BC}$ solution and the temperature at a concentration is $0.5 \%$. However, with the increasing of temperature, the apparent viscosity of the BC solution decreased, because when temperature raised, the activity of molecular chains is enhanced, resulting in better mobility of the solution. An appropriate electrostatic spinning condition of $25^{\circ} \mathrm{C}$ and $1.5 \%$ is chosen at last, by overall consideration of the membrane forming and droplets.

3.1.2. Morphology Analysis. Figure 2(a) shows the nanofiber (diameters about 30-60 nm) of BC biosynthesis by Acetobacter xylinum and the length ranging from several microns to several ten microns. The average diameters of electrospun fibers of increasing BC concentration from $1.2 \mathrm{wt} \%$ to $1.35 \mathrm{wt} \%$ are $150-200 \mathrm{~nm}$ (Figure 2(b)), $215-350 \mathrm{~nm}$ (Figure 2(c)), 270-400 nm (Figure 2(d)), and 500-800 nm (Figure 2(e)), respectively. Fibers diameters increase with the increasing $\mathrm{BC}$ concentration. At low concentrations, molecular chains entangle little, where the jet stretching by static electric power is strong, so the diameter of fiber is superfine. When the concentrations are increasing, the effect of molecular chain entanglement is enhanced. Jet stretching by static electric power decreased; as a consequence the diameter increased gradually. In Figure 2(f), the spinning voltage was $17 \mathrm{kV}$, the concentration was $1.35 \mathrm{wt} \%$, and the average diameters of spinning fibers were $200-300 \mathrm{~nm}$, smaller than Figure $2(\mathrm{~d})(16 \mathrm{kV}, 1.35 \mathrm{wt} \%)$. This is mainly due to surface charge density of electrospinning solution increasing with electric field strength, forming a larger electrostatic repulsion. At the same time, higher electric field strength results in stronger acceleration on jet. All of these factors can affect jet and fiber, eventually resulting in a greater tensile stress. To sum up, the optimum spinning voltage is $16-17 \mathrm{kV}$ and the temperature is $25^{\circ} \mathrm{C}$. The optimum concentration of the $\mathrm{BC}$ spinning solution was $1.3 \mathrm{wt} \%-1.35 \mathrm{wt} \%$.

Figures 2(g)-2(i) show the SEM photographs of BC membranes with different contents of $\mathrm{TiO}_{2}$. The spinning voltage was set at $16 \mathrm{kV}$. Temperature was $25^{\circ} \mathrm{C}$ and the concentration of the BC spinning solution was $1.35 \mathrm{wt} \%$. In the photographs, we can see that the surface of spinning fibers became rougher after doping with $\mathrm{TiO}_{2}$ nanoparticles and the diameter distribution was relatively concentrated at $300-500 \mathrm{~nm}$. Average diameter decreased slightly with increasing of $\mathrm{TiO}_{2}$ proportion. These are mainly because the surface tension of spinning solution decreased after being 


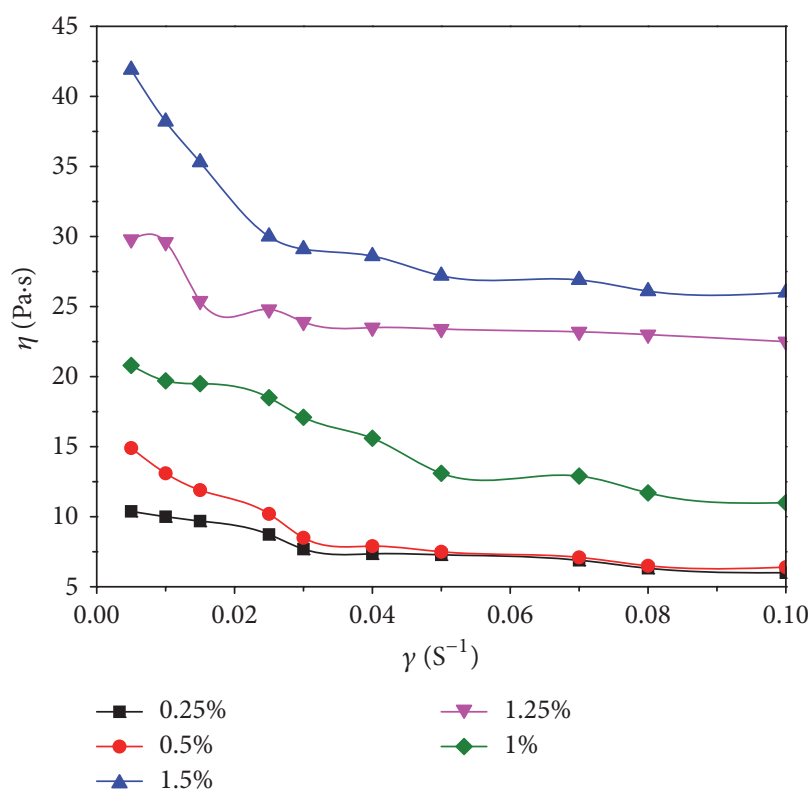

(a)

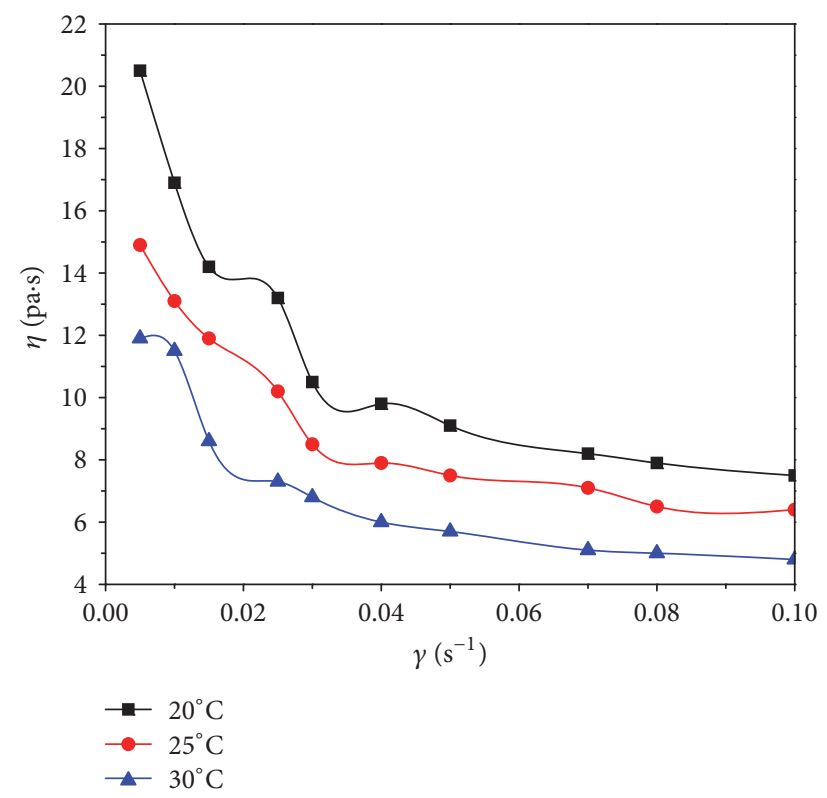

(b)

FIGURE 1: Effect of (a) cellulose concentration and (b) temperature on the apparent viscosity of the solution. $\gamma$ is the mass fraction of BC in the $\mathrm{BC}$ solution.

doped with $\mathrm{TiO}_{2}$. However, when the contents of $\mathrm{TiO}_{2}$ surpassed $0.05 \mathrm{~g}$, they tend to aggregate. At last, $0.05 \mathrm{~g} \mathrm{TiO}_{2}$ was chosen.

3.1.3. XRD and XPS Analysis. Figure 3(a) shows the XRD spectra of native BC (black curve, (i)) and regenerated BC fibers (red curve, (ii)). Native BC shows three strong Bragg peaks at $14.6^{\circ}, 16.9^{\circ}$, and $22.7^{\circ}$, which are indexed as the (101), $(10 \overline{1})$, and (002) peaks of the typical cellulose I structure, respectively. In the curve of the regenerated $\mathrm{BC}$ fibers, we found road peak with high background noise that reveals an amorphous structure. The degree of crystallinity and the crystallite sizes are calculated from XRD data using $C_{I}=$ $\left(I_{C} /\left(I_{C}+I_{O}\right)\right) \times 100 \%$. They clearly demonstrate that the degree of crystallinity of native $\mathrm{BC}$ was $74.14 \%$, but crystallite sizes of the regenerated BC fibers were $60.2 \%$. The crystallite sizes of the regenerated $\mathrm{BC}$ fibers were apparently smaller than the native $\mathrm{BC}$, since the growing of crystallites after regeneration was incomplete.

Figure 3(b) shows the XRD spectra of spinning BC (i), $0.1 \mathrm{~g} \mathrm{TiO}_{2} / \mathrm{BC}$ composite fiber (ii), and $\mathrm{TiO}_{2}$ (iii). In curve (iii), $\mathrm{TiO}_{2}$ shows six strong Bragg peaks at about $2 \theta=25.2^{\circ}$, $38.4^{\circ}, 48.1^{\circ}, 54.3^{\circ}, 54.5^{\circ}$, and $62.4^{\circ}$ which are indexed as the (101), (004), (200), (105), (211), and (224) peaks of the typical anatase $\mathrm{TiO}_{2}$ structure, respectively. These results indicate that we have successfully prepared anatase $\mathrm{TiO}_{2}$ by hydrothermal method. In the XRD curve of the $0.1 \mathrm{~g} \mathrm{TiO}_{2} / \mathrm{BC}$ composite fibers (curve (ii)), we find some new peaks which corresponded to $\mathrm{TiO}_{2}$ and road peak is hidden, which may be due to the strong peaks of $\mathrm{TiO}_{2}$. These results also reflect the successful preparation of $\mathrm{TiO}_{2} / \mathrm{BC}$ composite fibers.

Figure 3(e) shows the mapping photograph of Ti element in electrospinning fiber membrane. In the photograph we can see that $\mathrm{TiO}_{2}$ uniformly dispersed in spinning fiber. Figures 3(c)-3(d) show the XPS spectrum of $\mathrm{TiO}_{2} / \mathrm{BC}$ hybrid fiber and narrow spectrum of Ti element. In Figure 3(c), three elements $(\mathrm{C}, \mathrm{O}$, and $\mathrm{Ti}$ ) are found on the sample surface. The Ti 2P XPS peak of Ti in Figure 3(d) consists of two energy levels of Ti $2 \mathrm{P}_{1 / 2}$ and $2 \mathrm{P}_{3 / 2}$ at $463.5 \mathrm{ev}$ and $471.5 \mathrm{ev}$. The spectrum peaks were consistent with $\mathrm{TiO}_{2}$, which indicated the successfully prepared $\mathrm{TiO}_{2} / \mathrm{BC}$ composite fibers.

3.1.4. TGA and FT-IR Analysis. Figure 4(a) shows the TGA spectra of spinning $\mathrm{BC}$ fiber and nanocomposites fibers with different contents of $\mathrm{TiO}_{2}$. The curve of the spinning $\mathrm{BC}$ fiber shows that the weight loss was caused by the evaporation of the $\mathrm{H}_{2} \mathrm{O}$ from $50^{\circ} \mathrm{C}$ to $120^{\circ} \mathrm{C}$. Further weight loss from $300^{\circ} \mathrm{C}$ to $380^{\circ} \mathrm{C}$ was relatively fast, which was due to dehydration and decomposition of the molecules. The mass decreased about $89.5 \%$. From $390^{\circ} \mathrm{C}$ to $600^{\circ} \mathrm{C}$, the mass was almost unchanged. These indicated that cellulose decomposed completely. However, the decomposition temperature of $0.01 \mathrm{~g}$ $\mathrm{TiO}_{2} / \mathrm{BC}$ composite fiber was higher than pure spinning BC. Moreover, the residual mass was $16.5 \%$ after $390^{\circ} \mathrm{C}$, and it increased about $7 \%$ compared with pure spinning BC fiber. When the content of $\mathrm{TiO}_{2}$ increased to $0.1 \mathrm{~g}$, the dehydration and decomposition of the molecules began at $320^{\circ} \mathrm{C}$, and the residual mass was $33.5 \%$. It increased about $28 \%$ compared with pure spinning $\mathrm{BC}$ fiber. All of above showed that the thermal stability of $\mathrm{TiO}_{2} / \mathrm{BC}$ composite fiber was better than pure spinning $\mathrm{BC}$ fiber.

Figure 4(b) shows the FT-IR spectra of AAEM (A), $\mathrm{TiO}_{2} / \mathrm{BC}$ hybrid fibers (B), and native $\mathrm{BC}(\mathrm{C})$. From the figure we can see that both the native $\mathrm{BC}$ and hybrid fibers show similar FT-IR spectra, which means there is no significant 


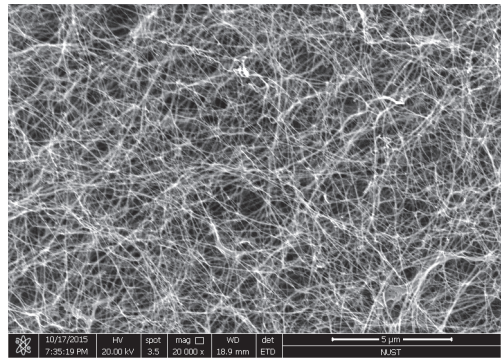

(a)

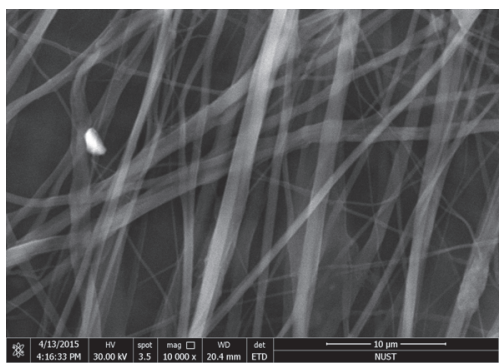

(d)

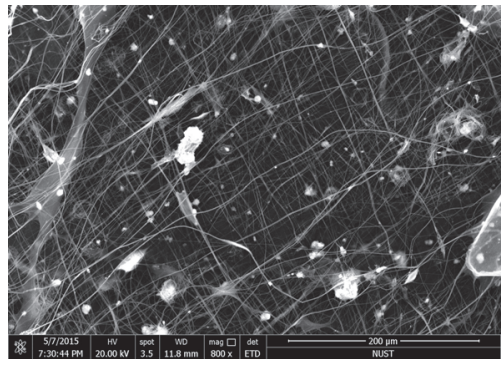

(g)

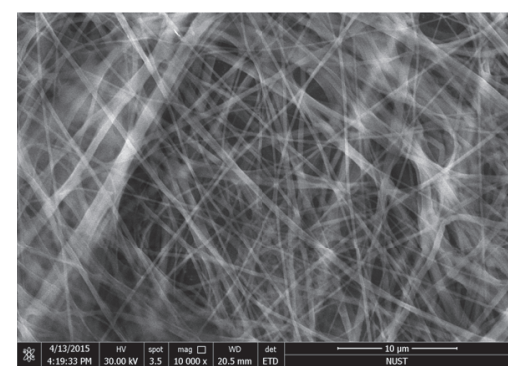

(b)

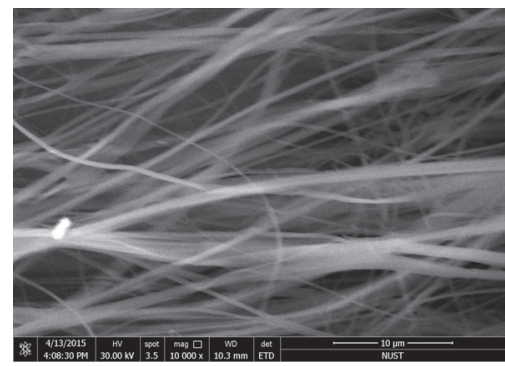

(e)

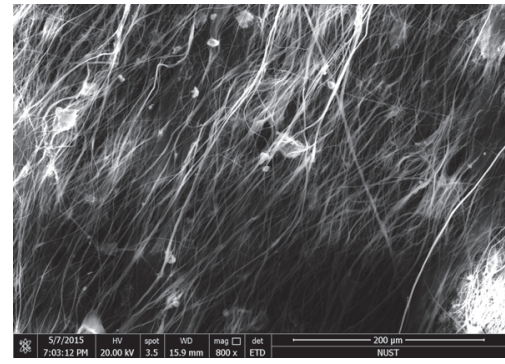

(h)

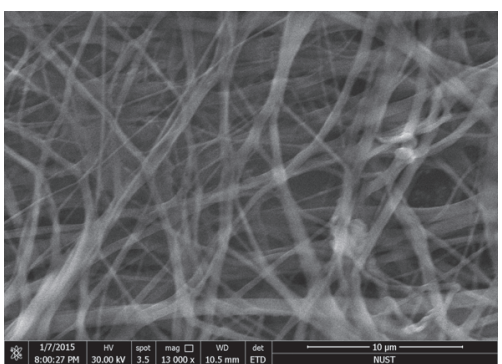

(c)

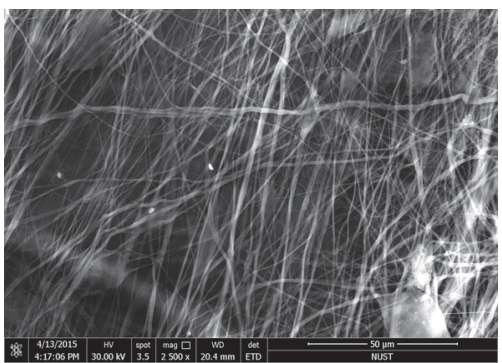

(f)

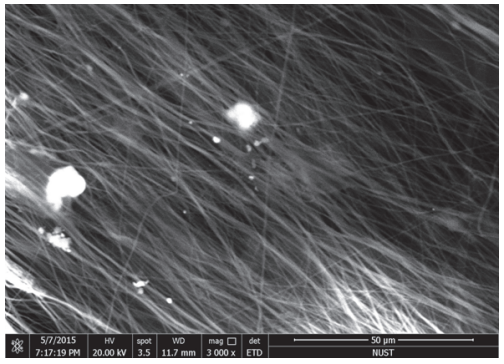

(i)

Figure 2: SEM photographs of (a) native BC, (b-f) regenerated BC fibers, (g) $0.1 \mathrm{~g} \mathrm{TiO}_{2} / 1.35 \% \mathrm{BC}$, (h) $0.05 \mathrm{~g} \mathrm{TiO}_{2} / 1.35 \% \mathrm{BC}$, and (i) $0.01 \mathrm{~g}$ $\mathrm{TiO}_{2} / \% 1.35$ BC.

TABLE 1: Influence of the reaction conditions on the degree of substitute (DS) of the product.

\begin{tabular}{lccccc}
\hline Samples & Molar ratio & Temperature $\left({ }^{\circ} \mathrm{C}\right)$ & Time $(\mathrm{h})$ & DS & IEC $(\mathrm{mmol} / \mathrm{g})$ \\
\hline 1 & 1 & 25 & 4 & 0.3145 & 0.25 \\
2 & 1.2 & 45 & 4 & 0.4890 & 0.4414 \\
3 & 1.3 & 60 & 4 & 0.9305 & 0.40 \\
4 & 1.4 & 25 & 8 & 0.6519 & 0.89 \\
5 & 1.6 & 60 & 8 & 0.7468 & 0.65 \\
6 & 1.8 & 25 & 16 & 1.438 & 0.99 \\
7 & 1.2 & 60 & 16 & 1.156 & 0.91 \\
\hline
\end{tabular}

Molar ratio: the molar ratio of $\mathrm{NaOH}$ to CHPTAC.

difference between the structure of the native $\mathrm{BC}$ and hybrid fibers. There were only some physical changes during the whole dissolving and spinning process. The most striking difference between native $\mathrm{BC}$ and AAEM spectra was the peak obtained for AAEM at $1481 \mathrm{~cm}^{-1}$, which corresponded to the methyl groups of ammonium. Moreover, the peak of AAEM positioned at $1418 \mathrm{~cm}^{-1}$ was referenced as the C-N stretching vibration [26-28]. FT-IR spectra have given an evidence of the introduction of the quaternary ammonium salt group on the cellulose backbone.

\subsection{Performance Test of Grafted Membrane}

3.2.1. Degree of Substitution and Ionic Conductivity. From Table 1, we found that when the mole ratio of alkali to etherified reagent was 1.2, the degree of substitute of product 


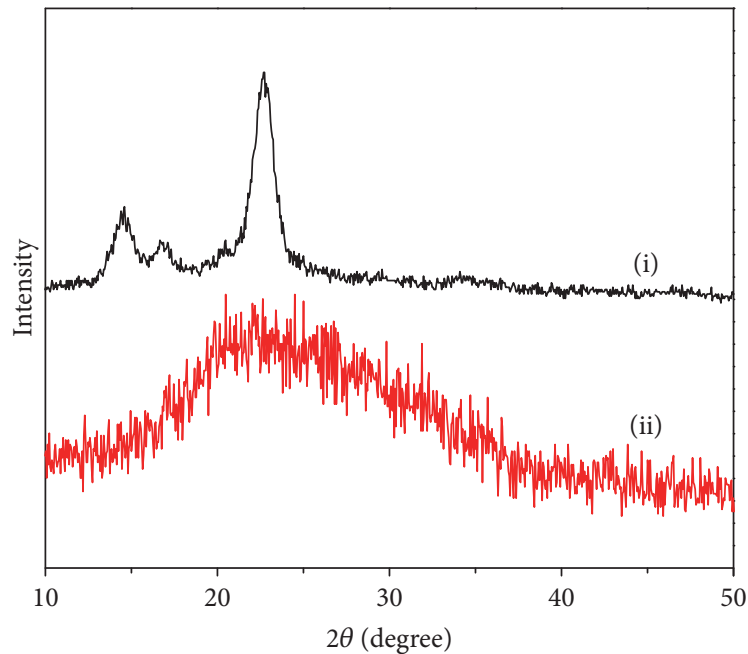

(a)

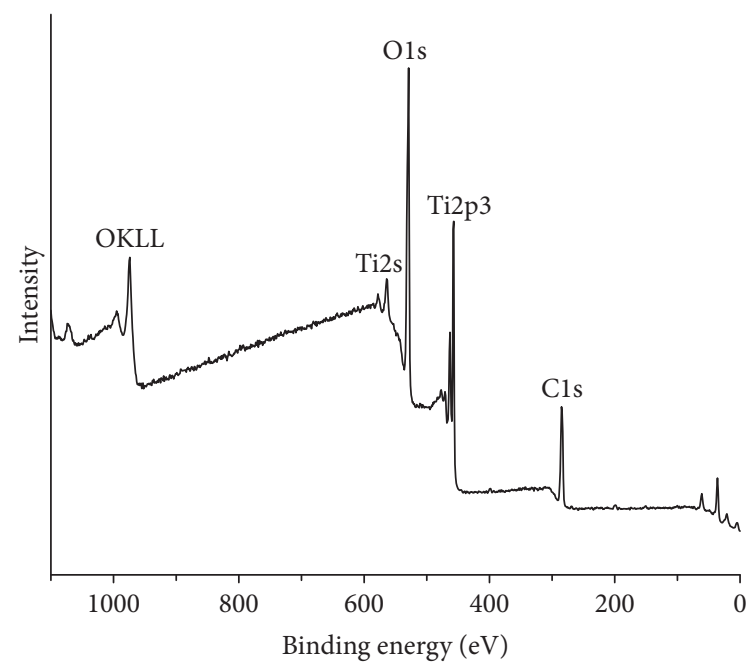

(c)

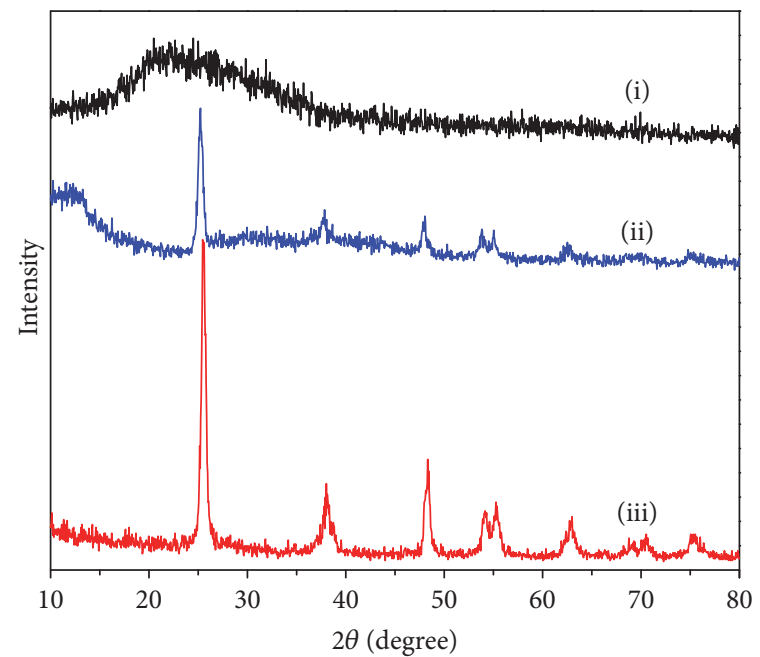

(b)

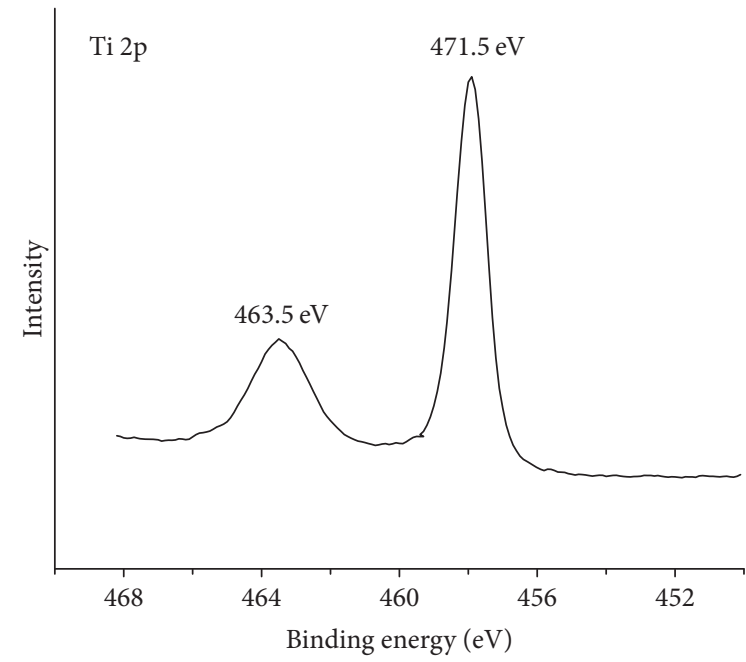

(d)

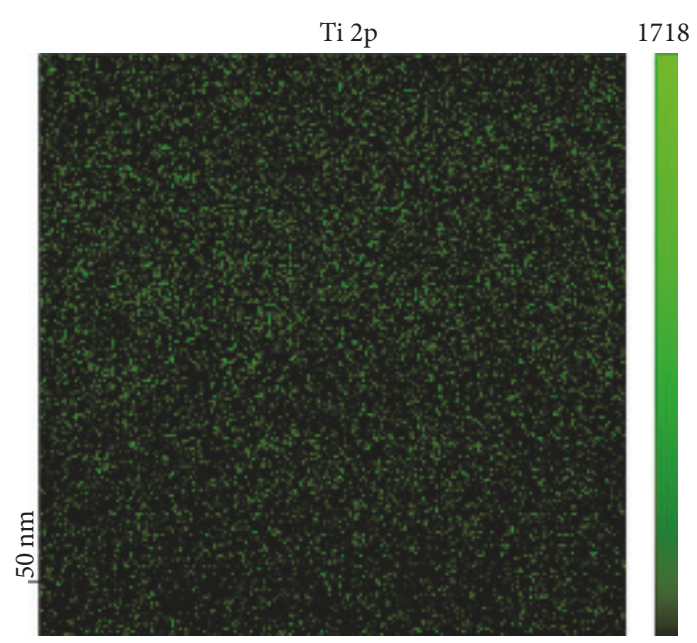

(e)

FIGURE 3: (a) XRD patterns of $\mathrm{BC}$ and regenerated $\mathrm{BC}$ fibers; (b) XRD patterns of spinning fiber, $0.1 \mathrm{~g} \mathrm{TiO}_{2} / \mathrm{BC}$ composite fiber, and TiO${ }_{2}$; (c) XPS spectrum of $\mathrm{TiO}_{2} / \mathrm{BC}$ hybrid fiber; (d) narrow spectrum of Ti element; (e) the mapping of Ti element in fiber membrane. 


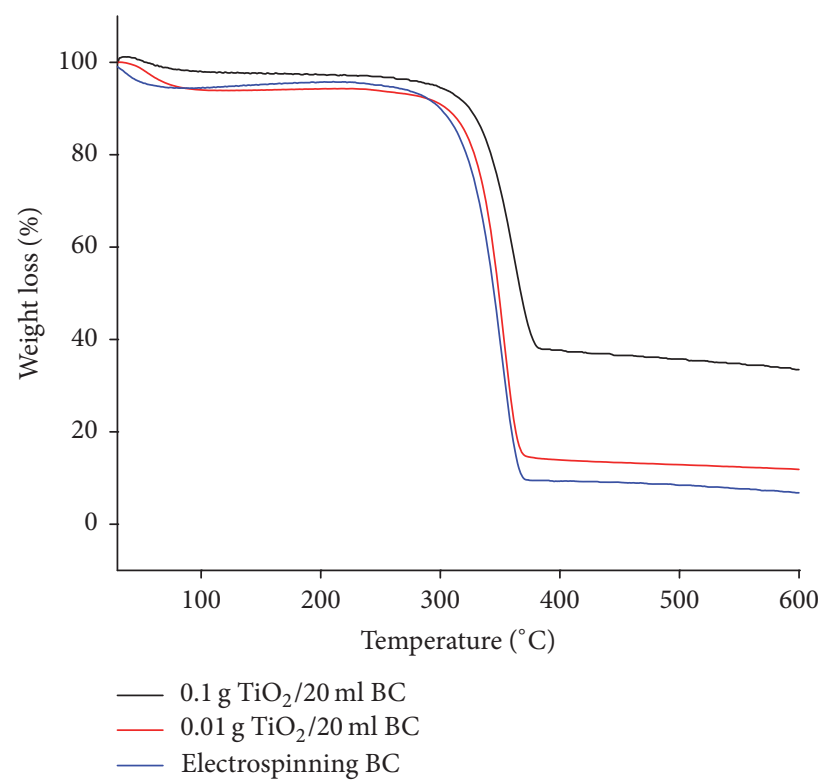

(a)

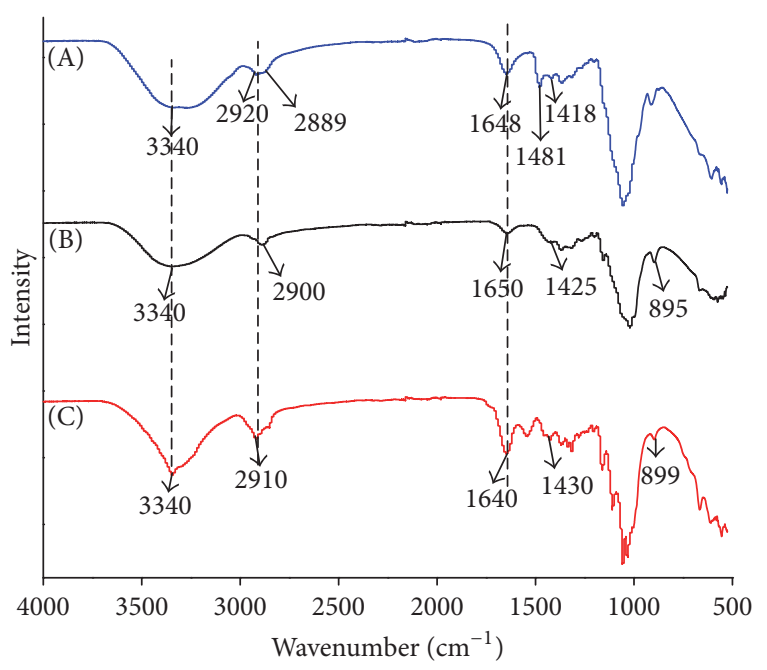

(b)

Figure 4: (a) TGA curves of $\mathrm{BC}$ and $\mathrm{TiO}_{2} / \mathrm{BC}$ nanofibers; (b) FT-IR spectrum of $\mathrm{AAEM}, \mathrm{TiO}_{2} / \mathrm{BC}$ hybrid fibers, and native $\mathrm{BC}$.

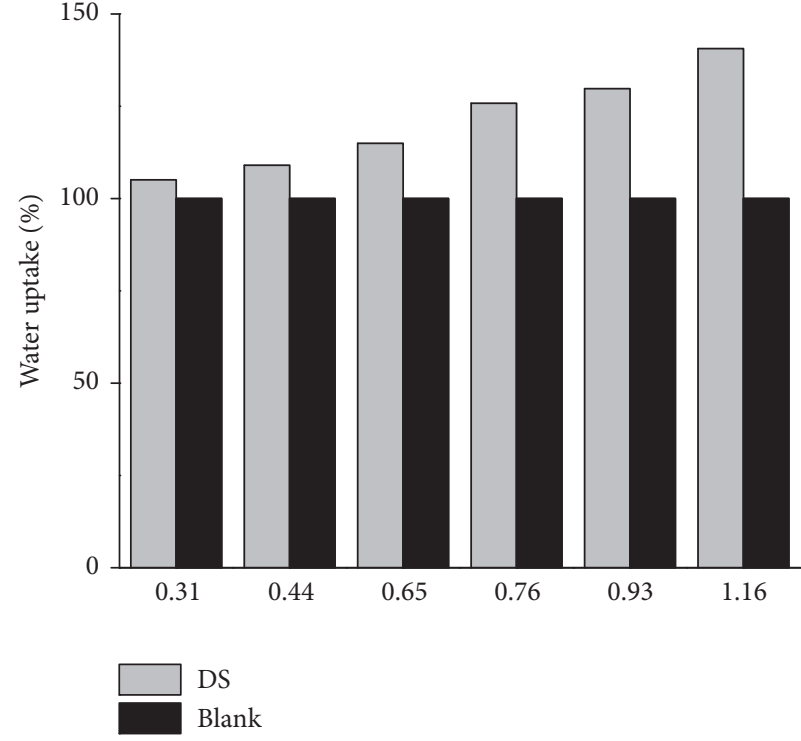

(a)

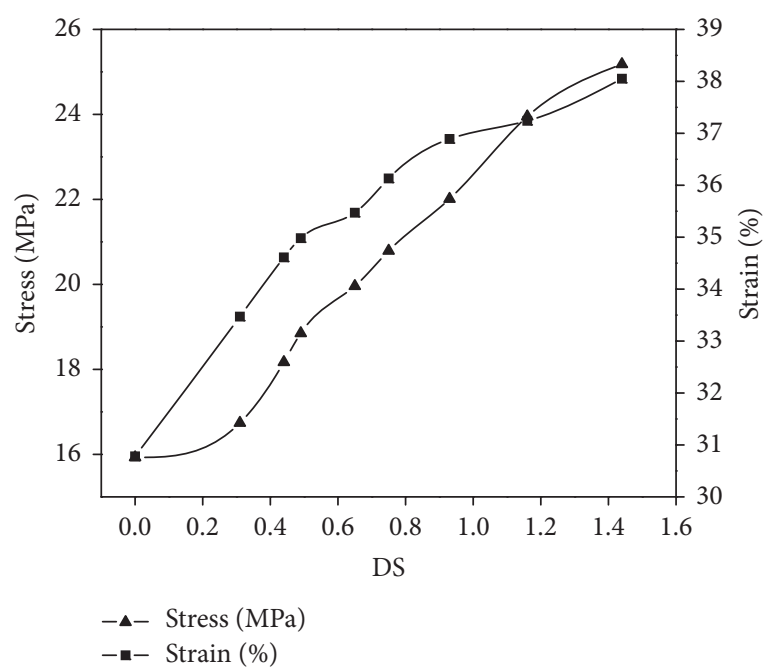

(b)

Figure 5: (a) Effect of the DS of the product on the water uptake; (b) mechanical property of the $\mathrm{TiO}_{2} / \mathrm{BC} / \mathrm{CHPTAC}-\mathrm{OH} / \mathrm{PVA}$ membranes with different DS.

was optimal. When the mole ratio was higher than 1.2 , more product from side reaction happened. It is easy to understand that a lower mole ratio below 1.2 will result in inadequate reaction substrates, also resulting in lower DS. As the degree of substitute increased with the reaction time, it arrives high to 1.438 after $16 \mathrm{~h}$.

From Table 1, we found that the IEC of membranes increased with the increase of DS. As for sample 7, its DS was 1.438; the IEC was as high as $0.99 \mathrm{mmol} \cdot \mathrm{g}^{-1}$. It increased significantly compared with QAPVA/HACC/GA alkaline membrane (0.822 mmol/g) [29] and increased onefold when compared with $\mathrm{SiO}_{2} / \mathrm{QAPVA}(0.57 \mathrm{mmol} / \mathrm{g})[10]$. These indicated that the composite membranes have the potential to apply as the membrane of alkali anion exchange membrane in fuel cell.

3.2.2. Water Uptake and Mechanical Properties. Electrochemical properties of fuel cell are significantly influenced by the water uptake of membranes. Sufficient water can provide enough carriers to ion migration. Figure 5(a) showed the 
TABLE 2: Swelling properties of composite membrane.

\begin{tabular}{lccccc}
\hline Number & DS & $S / \mathrm{cm}^{2}$ & $\Delta S / \mathrm{cm}^{2}$ & $\Delta S / S(\%)$ & 1.15 \\
2 & 0 & 4.0 & 0.046 & 1.54 & 15.82 \\
2 & 0.3145 & 4.0 & 0.0616 & 1.71 & 1.83 \\
3 & 0.4414 & 4.0 & 0.0684 & 2.28 & 17.54 \\
4 & 0.489 & 4.0 & 0.0732 & 2.42 & 18.99 \\
5 & 0.6519 & 4.0 & 0.0912 & 2.76 & 20.01 \\
6 & 0.7468 & 4.0 & 0.0968 & 3.01 & 20.78 \\
7 & 0.9305 & 4.0 & 0.12 & 3.39 \\
9
\end{tabular}

${ }^{*} \Delta S$ is area change: $\Delta S=S^{\prime}-S ; S=L x \cdot L y ; \Delta V$ is volume change: $\Delta V=V^{\prime}-V ; V=L x \cdot L y \cdot L z$.

effect of the DS of the product on the water uptake. From the figure, we found that the water uptake of alkaline composite membranes increased with the increase in DS of the grafting reaction, and the water uptake was higher than the membranes without graft. The water uptake was up to $140 \%$ when the DS was 1.16. It is similar in the condition of $\mathrm{SiO}_{2} /$ QPVA [29] alkaline composite membranes. The most high water uptake was $167 \%$. The introduction of hydrophilic hydroxyl group and quaternary ammonium groups increases the hydrophilicity of composite membrane.

Figure 5(b) shows the mechanical property of the $\mathrm{TiO}_{2} /$ BC/CHPTAC-OH/PVA membranes of different DS. The mechanical performance of composite membranes was improved by joining the PVA at the room temperature. The tensile strength and the breaking elongation ratio of $\mathrm{TiO}_{2} /$ $\mathrm{BC} / \mathrm{CHPTAC}-\mathrm{OH} / \mathrm{PVA}$ membranes increased with the increase of DS. We found that when grafting DS up to the maximum, the tensile strength of $\mathrm{TiO}_{2} / \mathrm{BC} / \mathrm{CHPTAC}$ $\mathrm{OH} / \mathrm{PVA}$ membranes is up to $25.18 \mathrm{MPa}$ and the breaking elongation ratio is up to $38.05 \%$. As the DS falls, both tensile strength and breaking elongation ratio came to the minimum. Main reasons resulting in the problems may be the reduction of quaternary ammonium and water, leading to tensile strength and breaking elongation ratio decrease.

3.2.3. Swelling Ratio of AAEM. Fuel cell is significantly influenced by the dimension stability of membranes. It is measured by swelling ratio of membranes. Table 2 shows the swelling properties of composite membranes. From it, it we found that the swelling ratio of pure $\mathrm{BC}$ spinning membranes was low, and the swelling ratio of area was only $1.15 \%$. The dimension stability of membranes was better. Moreover, the swelling ratio of composite membranes slightly increased with the increase in DS. These may be because the resulting hydrophilic quaternary amine groups are increased with the increase in DS, implying the improved hydrophilic properties of the membranes. The membranes become more hydrophilic and the swelling ratio increased.

3.2.4. Ionic Conductivity. Figure 6 shows the ionic conductivity of the composite films at different temperatures when the IEC was fixed at $0.99 \mathrm{mmol} / \mathrm{g}$. We can see that ionic conductivity of membranes gradually increases from 0.01 to

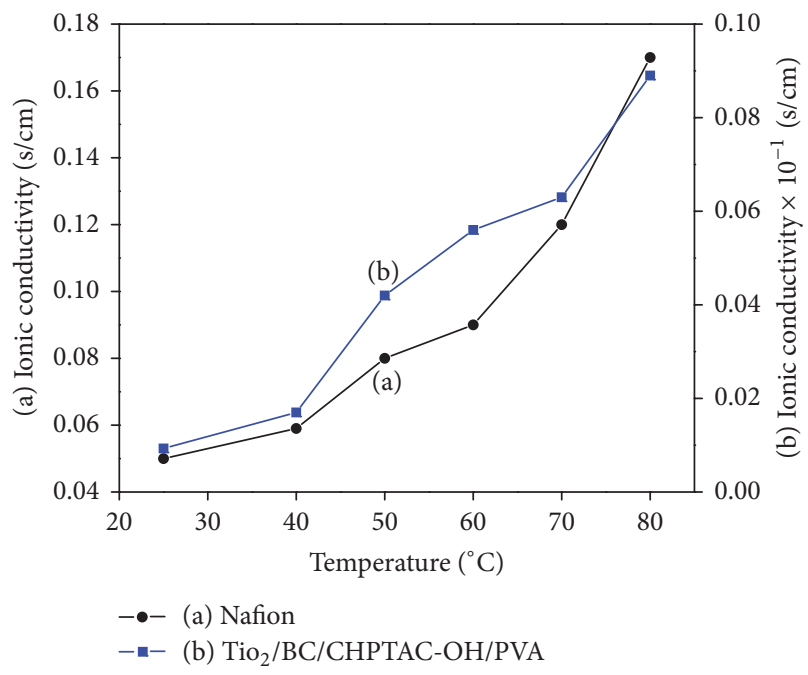

FIGURE 6: The ionic conductivity of the composite films at different temperatures.

$0.093 \mathrm{~s} / \mathrm{cm}$ as the increase of temperature raised from $25^{\circ} \mathrm{C}$ to $80^{\circ} \mathrm{C}$. This value was comparative to Nafion 117 in the $1 \mathrm{M}$ $\mathrm{H}_{2} \mathrm{SO}_{4}$ solution.

\section{Conclusions}

In this paper, we used the electrostatic spinning technology to prepare $\mathrm{BC} / \mathrm{TiO}_{2}$ nanofibers. Then $\mathrm{BC} / \mathrm{TiO}_{2} / \mathrm{CHPTAC}$ $\mathrm{OH} / \mathrm{PVA}$ membranes for alkaline fuel cells were prepared via quaternization and alkalization. The properties of the composite membrane including water uptake, swelling degree, mechanical properties, ion-exchange capacity, and ion conductivity were investigated. It was found that the obtained AAEMs exhibited high DS (1.16), when the molar ratio of alkali and CHPTAC is 1.2 and the reaction time is $16 \mathrm{~h}$. The water uptake and IEC of $\mathrm{BC} / \mathrm{TiO}_{2} / \mathrm{CHPTAC}$ membrane were $140 \%$ and $1 \mathrm{mmol} / \mathrm{g}$, respectively. Meanwhile, the composite membranes exhibited excellent dimensional stability. The mechanical properties of the composite films were improved by PVA and the $\mathrm{BC} / \mathrm{TiO}_{2} / \mathrm{CHPTAC}-\mathrm{OH} / \mathrm{PVA}$ alkaline anion exchange membrane with maximum degree 
of substitution exhibited better mechanical strength (stress: $25.18 \mathrm{MPa}$, strain: $38.05 \%)$. In addition, the ionic conductivity of the composite film was $0.0093 \mathrm{~s} / \mathrm{cm}$ at $80^{\circ} \mathrm{C}$. Compared with other commercial membranes, the as-prepared composite membrane exhibited comparable performances, thus promising many applications in fuel cells.

\section{Conflicts of Interest}

The authors declare that they have no conflicts of interest.

\section{Acknowledgments}

The authors acknowledge the financial support from the National Natural Science Foundation of China (no. 21206076) and the Natural Science Foundation of Jiangsu Province (no. BK 2012401). This work was supported by Advanced Catalysis and Green Manufacturing Collaborative Innovation Center (Changzhou University), Synergetic Research Center for Advanced Micro-Nano-Materials and Technology of Jiangsu Province, and a project funded by the Priority Academic Program Development of Jiangsu Higher Education Institutions (PAPD, China).

\section{References}

[1] R. Payne, J. Love, and M. Kah, "Generating electricity at $60 \%$ electrical efficiency from 1-2 kWe SOFC products," in Proceedings of the 11th International Symposium on Solid Oxide Fuel Cells (SOFC-XI)- 216th ECS Meeting, pp. 231-239, aut, October 2009.

[2] H. C. Patel, T. Woudstra, and P. V. Aravind, "Thermodynamic analysis of solid oxide fuel cell gas turbine systems operating with various biofuels," Fuel Cells, vol. 12, no. 6, pp. 1115-1128, 2012.

[3] L. van Biert, M. Godjevac, K. Visser, and P. V. Aravind, "A review of fuel cell systems for maritime applications," Journal of Power Sources, vol. 327, pp. 345-364, 2016.

[4] H. Guo, X. Liu, J. F. Zhao, F. Ye, and C. F. Ma, "Effect of low gravity on water removal inside proton exchange membrane fuel cells (PEMFCs) with different flow channel configurations," Energy, vol. 112, pp. 926-934, 2016.

[5] J. R. Varcoe and R. C. T. Slade, "Prospects for alkaline anionexchange membranes in low temperature fuel cells," Fuel Cells, vol. 5, no. 2, pp. 187-200, 2005.

[6] G. F. McLean, T. Niet, S. Prince-Richard, and N. Djilali, "An assessment of alkaline fuel cell technology," International Journal of Hydrogen Energy, vol. 27, no. 5, pp. 507-526, 2002.

[7] E. Agel, J. Bouet, and J. F. Fauvarque, "Characterization and use of anionic membranes for alkaline fuel cells," Journal of Power Sources, vol. 101, no. 2, pp. 267-274, 2001.

[8] G. Merle, S. S. Hosseiny, M. Wessling, and K. Nijmeijer, "New cross-linked PVA based polymer electrolyte membranes for alkaline fuel cells," Journal of Membrane Science, vol. 409-410, pp. 191-199, 2012.

[9] D. S. Kim, H. B. Park, J. W. Rhim, and Y. M. Lee, "Preparation and characterization of crosslinked $\mathrm{PVA} / \mathrm{SiO}_{2}$ hybrid membranes containing sulfonic acid groups for direct methanol fuel cell applications," Journal of Membrane Science, vol. 240, no. 1-2, pp. 37-48, 2004.
[10] Y. Xiong, Q. L. Liu, Q. G. Zhang, and A. M. Zhu, "Synthesis and characterization of cross-linked quaternized poly(vinyl alcohol)/chitosan composite anion exchange membranes for fuel cells," Journal of Power Sources, vol. 183, no. 2, pp. 447-453, 2008.

[11] D. Klemm, D. Schumann, U. Udhardt, and S. Marsch, "Bacterial synthesized cellulose - artificial blood vessels for microsurgery," Progress in Polymer Science, vol. 26, no. 9, pp. 1561-1603, 2001.

[12] A. Svensson, E. Nicklasson, T. Harrah et al., "Bacterial cellulose as a potential scaffold for tissue engineering of cartilage," Biomaterials, vol. 26, no. 4, pp. 419-431, 2005.

[13] D. H. Reneker, A. L. Yarin, E. Zussman, and H. Xu, "Electrospinning of nanofibers from polymer solutions and melts," Advances in Applied Mechanics, vol. 41, pp. 43-195, 2007.

[14] C.-W. Kim, M. W. Frey, M. Marquez, and Y. L. Joo, "Preparation of submicron-scale, electrospun cellulose fibers via direct dissolution," Journal of Polymer Science, Part B: Polymer Physics, vol. 43, no. 13, pp. 1673-1683, 2005.

[15] C.-W. Kim, D.-S. Kim, S.-Y. Kang, M. Marquez, and Y. L. Joo, "Structural studies of electrospun cellulose nanofibers," Polymer, vol. 47, no. 14, pp. 5097-5107, 2006.

[16] J. Doshi and D. H. Reneker, "Electrospinning process and applications of electrospun fibers," Journal of Electrostatics, vol. 35, no. 2-3, pp. 151-160, 1995.

[17] C. Sanchez, B. Julián, P. Belleville, and M. Popall, "Applications of hybrid organic-inorganic nanocomposites," Journal of Materials Chemistry, vol. 15, no. 35-36, pp. 3559-3592, 2005.

[18] G. Kickelbick, "Concepts for the incorporation of inorganic building blocks into organic polymers on a nanoscale," Progress in Polymer Science, vol. 28, no. 1, pp. 83-114, 2003.

[19] V. Baglio, A. S. Aricò, V. Antonucci et al., "An NMR spectroscopic study of water and methanol transport properties in DMFC composite membranes: Influence on the electrochemical behaviour," Journal of Power Sources, vol. 163, no. 1, pp. 52-55, 2006.

[20] Y.-F. Lin, C.-Y. Yen, C.-H. Hung, Y.-H. Hsiao, and C.-C. M. Ma, "A novel composite membranes based on sulfonated montmorillonite modified Nafion ${ }^{\circledR}$ for DMFCs," Journal of Power Sources, vol. 168, no. 1, pp. 162-166, 2007.

[21] E. N. Gribov, E. V. Parkhomchuk, I. M. Krivobokov, J. A. Darr, and A. G. Okunev, "Supercritical CO2 assisted synthesis of highly selective nafion-zeolite nanocomposite membranes for direct methanol fuel cells," Journal of Membrane Science, vol. 297, no. 1-2, pp. 1-4, 2007.

[22] F. Bauer and M. Willert-Porada, "Microstructural characterization of $\mathrm{Zr}$-phosphate-Nafion ${ }^{\circledR}$ membranes for direct methanol fuel cell (DMFC) applications," Journal of Membrane Science, vol. 233, no. 1-2, pp. 141-149, 2004.

[23] P. Carballeira and F. Haupert, "Toughening effects of titanium dioxide nanoparticles on TiO 2/epoxy resin nanocomposites," Polymer Composites, vol. 31, no. 7, pp. 1241-1246, 2010.

[24] C.-C. Yang, "Synthesis and characterization of the cross-linked $\mathrm{PVA} / \mathrm{TiO} 2$ composite polymer membrane for alkaline DMFC," Journal of Membrane Science, vol. 288, no. 1-2, pp. 51-60, 2007.

[25] D. Sun, L. Zhou, Q. Wu, and S. Yang, "Preliminary research on structure and properties of nano-cellulose," Journal Wuhan University of Technology, Materials Science Edition, vol. 22, no. 4, pp. 677-680, 2007. 
[26] E. Loubaki, M. Ourevitch, and S. Sicsic, "Chemical modification of chitosan by glycidyl trimethylammonium chloride. characterization of modified chitosan by $13 \mathrm{C}$ - and $1 \mathrm{H}-\mathrm{NMR}$ spectroscopy," European Polymer Journal, vol. 27, no. 3, pp. 311-317, 1991.

[27] M. Kačuráková, A. Ebringerová, J. Hirsch, and Z. Hromádková, "Infrared study of arabinoxylans," Journal of the Science of Food and Agriculture, vol. 66, no. 3, pp. 423-427, 1994.

[28] S. Pal, D. Mal, and R. P. Singh, "Cationic starch: an effective flocculating agent," Carbohydrate Polymers, vol. 59, no. 4, pp. 417-423, 2005.

[29] Y. Xiong, Q. L. Liu, A. M. Zhu, S. M. Huang, and Q. H. Zeng, "Performance of organic-inorganic hybrid anion-exchange membranes for alkaline direct methanol fuel cells," Journal of Power Sources, vol. 186, no. 2, pp. 328-333, 2009. 

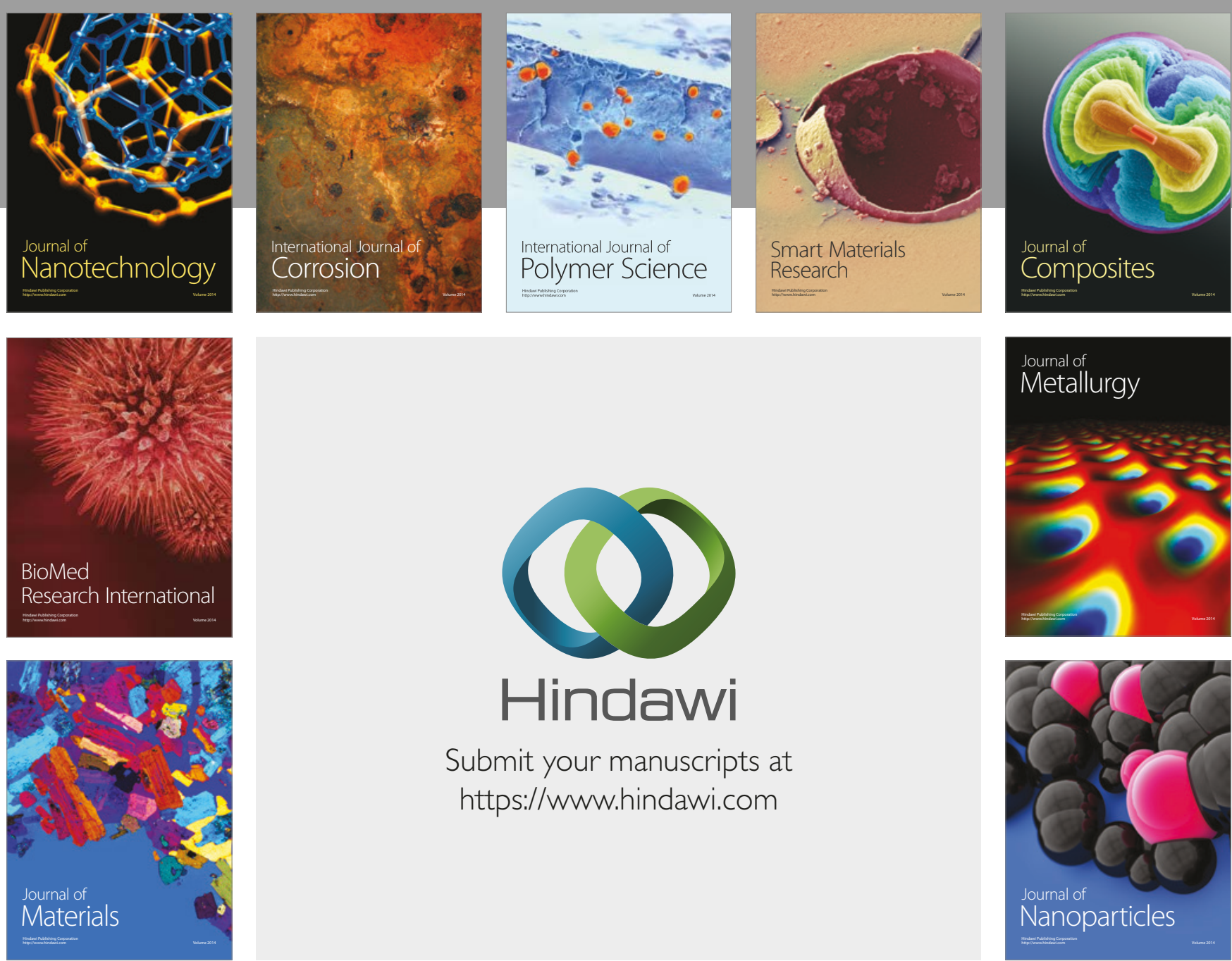

\section{Hindawi}

Submit your manuscripts at

https://www.hindawi.com
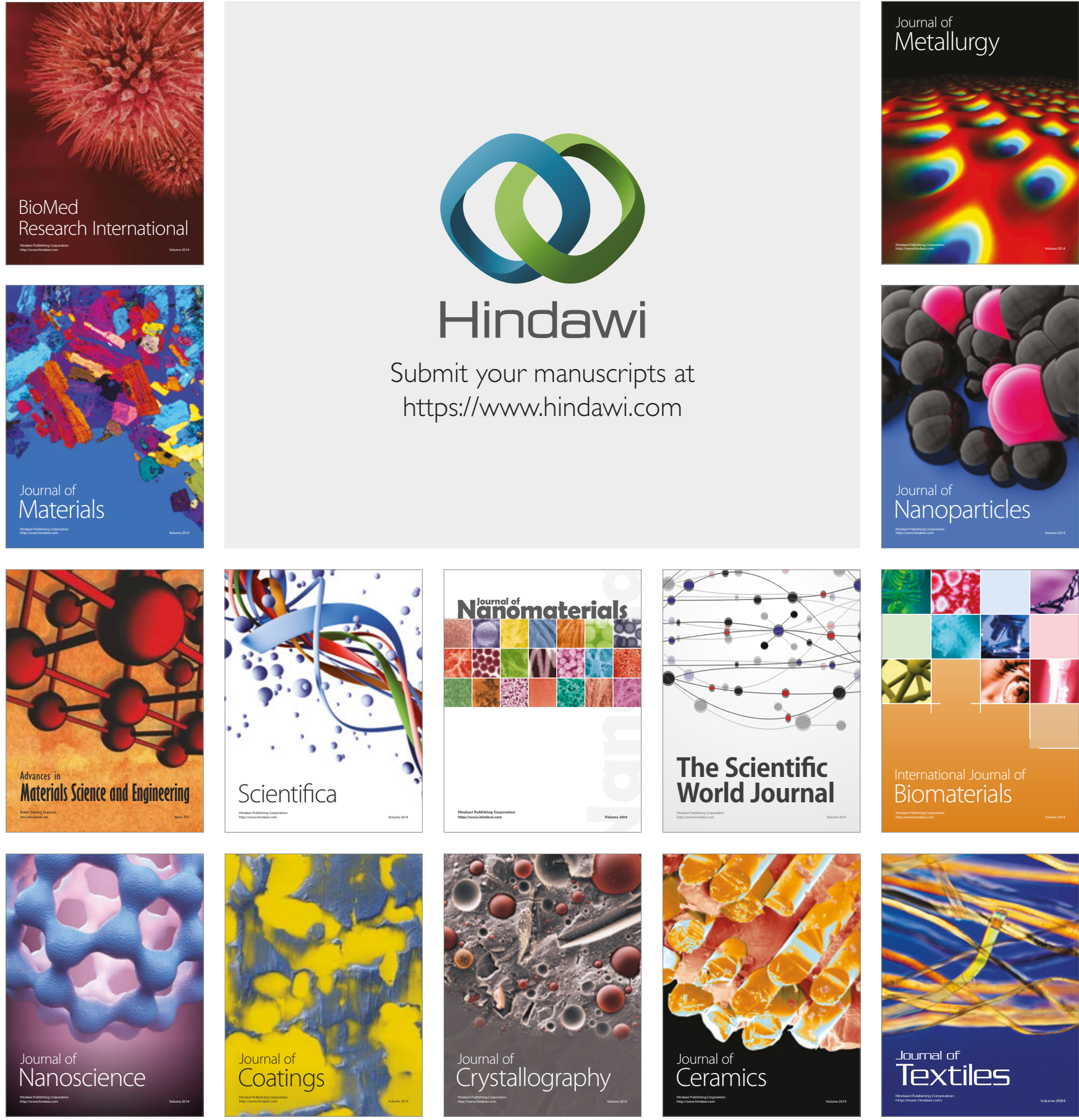

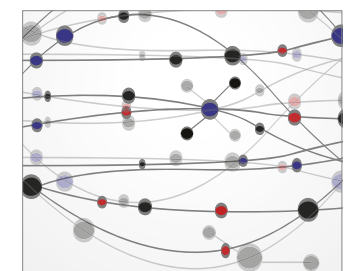

The Scientific World Journal
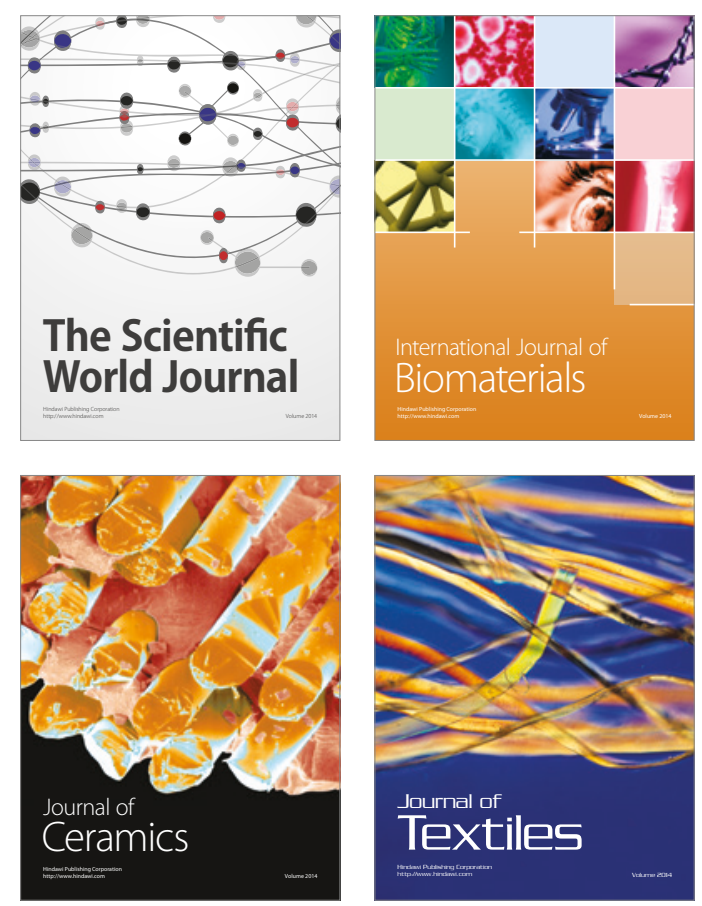